\title{
PENINGKATAN KEMAMPUAN MENULIS TEKS PIDATO DENGAN MENGGUNAKAN METODE THINK FAIR SHARE
}

\author{
Gagan Zakaria Sidik \\ Universitas Suryakancana \\ zakariasidikpbsi2a@gmail.com
}

\begin{abstract}
This article discusses improving the ability to write speech text by using think fair share method. The study was conducted using Classroom Action Research (PTK) with two cycles. Technique of collecting data is done by test. The results showed that there was an increase in the ability to write speech texts and student activities. This can be seen in the cycle I the ability to write speech text with completeness reached $60.68 \%$ or 70 average. Then it looks a significant increase compared to cycle I, in cycle II mastery reaches $91.30 \%$ or an average of 82.34. Furthermore, students' activity in cycle I was recorded by 4 students or $17.39 \%$ who played mobile phone, 3 students or $13.04 \%$ who were relaxed waiting for the reply from their friends, and 2 students or $8.69 \%$ who cheered his friend when doing. Compared to cycle I, some students do not want to do themselves according to the instructions. In the implementation of cycle II, the activity of students who play mobile phone decreased from 4 students or by $17.39 \%$ to 2 students or by $8.69 \%$, relaxed students waiting for answers from their friends no, and students who bully his friend does not exist.
\end{abstract}

Keywords: writing text of speech, think fair share.

\section{PENDAHULUAN}

Belajar berbahasa berarti bagaimana menggunakan bahasa itu sebagai alat komunikasi, baik secara lisan maupun tulis, seperti menulis teks pidato. Karena itu, kehadiran pembelajaran keterampilan menulis yang terencana dengan baik dirasakan sangat perlu, karena keterampilan menulis merupakan bagian dari keterampilan berbahasa yang mutlak perlu dimiliki oleh setiap siswa. Menulis merupakan kegiatan produkif.

"Menulis adalah menurunkan atau melukiskan lambang-lambang grafik yang menggambarkan suatu bahasa yang dipahami oleh seseorang, sehingga orang-orang lain dapat membaca lambang-lambang grafik tersebut kalau mereka memahami bahasa dan gambaran grafik itu." (Tarigan, 2008: 22)

Sesuai dengan perkembangan zaman dan sifat bahasa yang dinamis pengertian di atas dikembangkan oleh para ahli bahasa selanjutnya.

Menurut Zainurrahman (2011: 2) mengungkapkan bahwa "menulis merupakan salah satu dari empat keterampilan berbahasa yang mendasar (berbicara, mendengar, menulis, dan membaca). Dewasa ini, keterampilan berpikir kritis (critical thinking) dan literasi (literacy skill) sudah menjadi keterampilan berbahasa lanjut (advanced linguistic skill)."

Pendapat Dalman (2014:4) bahwa "menulis adalah proses penyampaian pikiran, angan-angan, perasaan dalam bentuk lambang/tanda/tulisan yang bermakna, melukiskan suatu lambang/tanda/tulisan berupa kumpulan huruf yang membentuk kata atau kalimat, kumpulan kalimat membentuk paragraf, dan kumpulan paragraf membentuk wacana/karangan yang utuh dan bermakna."

"Menulis naskah pidato pada hakikatnya adalah menuangkan gagasan ke dalam bentuk 
bahasa tulis yang siap dilisankan. Pilihan kosakata, kalimat, dan paragraf dalam menulis sebuah pidato sesungguhnya tidak jauh berbeda dengan kegiatan menulis naskah yang lain. Situasi resmi atau kurang resmi akan menentukan kosakata dalam menulis." (Arifin dan Tasai, 2015: 209)

Menurut Arifin dan Tasai (2015: 208) pidato yang baik ditandai oleh beberapa kriteria sebagai berikut. 1) isi pidato sesuai dengan kegiatan yang sedang berlangsung, 2) isinya menggugah dan bermanfaat bagi pendengar, 3) tidak menimbulkan pertentangan sara, 4) jelas, 5) benar dan objektif, 6) bahasa yang dipakai mudah dipahami, dan 7) disampaikan secara santun, rendah hati, dan bersahabat.

Menurut pengamatan dari data yang diberikan hasil nilai menulis teks pidato, nilai siswa kelas X-2 masih berada di bawah KKM yang ditentukan, dari KKM bahasa Indonesia 80. Secara lengkap, nilai menulis teks pidato dari hasil observasi sebagai berikut. 13 siswa nilainya dibawah 50, 7 siswa nilainya antara 50 sampai dengan 60 , dan 2 siswa yang nilainya 80. Dari nilai siswa tersebut, bisa dijelaskan bahwa kelemahan atau kekurangan siswa dalam menulis teks pidato sebagai berikut. (1) siswa kurang konsisten dalam hal pemakaian huruf kapital (huruf besar) baik pada awal kalimat, nama kota, nama orang, serta menulis setiap kata dalam kalimat dengan memakai huruf kapital, (2) banyak siswa yang menuliskan bentuk ulang dengan menggunakan angka 2, silang dua (xx), atau angka romawi (II), (3) penggunaan kalimat yang kurang efektif, (4) banyak siswa yang kurang konsisten dalam menyingkat kata, dan (5) siswa kurang bisa menggunakan pilihan kata dan struktur kalimat yang tepat.

Metode think fair share dipandang dapat meningkatkan kemampuan menulis teks pidato sesuai dengan kaidah bahasa. Menurut Yamin (2013:149) "metode pembel-ajaran merupakan cara guru melakukan atau menyajikan, menguraikan, memberi contoh, dan memberi latihan isi pelajaran kepada peserta didik untuk mencapai tujuan tertentu. Metode cara guru menjelaskan konsep, fakta, dan prinsip kepada peserta didik dengan cara pendekatan pembelajaran berpusat pada guru (teacher oriented) dan pembelajaran berpusat pada peserta didik (student oriented)."

Dalam kenyataannya, cara atau metode pembelajaran yang digunakan untuk menyampaikan informasi berbeda dengan cara yang ditempuh untuk memantapkan siswa dalam menguasai pengetahuan, keterampilan, dan sikap.

Trianto (2010: 81) menjelaskan bahwa "think fair share atau berpikir berpasangan berbagi adalah jenis pembelajaran kooperatif yang dirancang untuk mempengaruhi interaksi siswa." Selanjutnya Shoimin, (2016: 208) berpendapat bahwa "think fair share adalah suatu model pembelajaran kooperatif memberi siswa waktu untuk berpikir dan merespons serta saling bantu satu sama lain."

Shoimin (2016:211) berpendapat bahwa langkah-langkah think fair share sebagai berikut.

1) Think (berpikir), yaitu guru memberikan pertanyaan atau masalah yang terkait dengan materi pelajaran.

2) Fair (berpasangan), guru meminta kepada siswa untuk berpasangan dan mulai memikirkan pertanyaan atau masalah yang diberikan guru dalam waktu tertentu. Lamanya waktu ditetapkan berdasarkan pemahaman guru terhadap siswanya, sifat pertanyaannya, dan jadwal pembelajaran. Siswa disarankan untuk menulis jawaban atau pemecahan masalah hasil pemikirannya.

3) Share (berbagi), siswa secara individu mewakili kelompok atau berdua maju bersama untuk melaporkan hasil diskusinya ke seluruh kelas.

Berdasarkan langkah-langkah di atas dapat disimpulkan bahwa siswa melakukan diskusi dalam dua tahap yaitu tahap berpasangan (fair), diskusi dengan teman 
sebangku. Kemudian, tahap berbagi (share), diskusi dengan seluruh teman sekelasnya.

\section{METODE PENELITIAN}

Metode yang digunakan penelitian tindakan kelas. Menurut Kemmis (dalam Sanjaya, 2009: 24) "penelitian tindakan kelas adalah suatu bentuk penelitian reflekstif dan kolektif yang dilakukan oleh peneliti dalam situasi sosial untuk meningkatkan penalaran praktik sosial mereka".

Desain penelitian terdiri dari 2 siklus. Masing-masing siklus memiliki 4 tahap yang dirumuskan oleh Hopkins sebagai berikut. 1) plan (perencanaan), 2) action (tindakan), 3) observation (observasi), dan 4) reflection (refleksi).

Subjek penelitian, siswa kelas X-2 SMA Pasundan 2 Cianjur. Siswa kelas X-2 berjumlah 23 orang, yang berjumlah 10 lak-laki dan 13 perempuan. Tempat penelitian di SMA Pasundan 2 Cianjur. Penelitian siklus I dilaksanakan hari Kamis 19 Januari 2017. Penelitian siklus II dilaksanakan hari Kamis 26 Januari 2017. Instrument penelitian menggunakan instrument tes. Teknik pengumpulan data menggunakan teknik tes. Teknik analisis data menggunakan analisis data kuantitatif.

\section{HASIL PENELITIAN}

Hasil penelitian tindakan kelas ini diperoleh dari prasiklus, siklus I, dan siklus II. Pembelajaran dilakukan dalam dua pertemuan. Dua pertemuan tersebut, yaitu pertemuan ke satu pada siklus I dan pertemuan ke dua pada siklus II.

Hasil pertemuan siklus I dan siklus II terdiri atas hasil tes. Hasil tes tersebut kemudian dianalisis untuk mengetahui peningkatan yang terjadi. Hasil tes siklus I merupakan hasil kemampuan menulis teks pidato untuk mengetahui kondisi awal siswa dalam menulis pidato menggunakan penerapan metode think fair share.
Hasil tes siklus II merupakan perbaikan tes kemampuan menulis teks pidato menggunakan penerapan metode think fair share. Hasil tes siklus I dan siklus II tersebut diuraikan dalam bentuk data kuantitatif.

Hasil tes prasiklus dari guru mata pelajaran bahasa Indonesia kelas X-2 SMA Pasundan 2 Cianjur yaitu sebelum dilaksanakan penelitian tindakan kelas dalam pembelajaran menulis teks pidato. Hasil tes prasiklus berfungsi untuk mengetahui seberapa besar kemampuan awal siswa dalam menulis teks pidato.

Dari hasil perhitungan diketahui bahwa hasil tes prasiklus kemampuan menulis teks pidato siswa mencapai total nilai 1230 dengan rata-rata 53,47 dalam kategori sangat kurang baik. Tidak ada siswa yang mencapai nilai dengan kategori sangat baik. Kategori baik (rentang nilai 80-89) terdapat 8 siswa yang mencapai nilai tersebut dengan persentase $34,78 \%$. Kategori cukup baik (rentang nilai 70-79) dicapai oleh 8 siswa atau dengan persentase $34,78 \%$.

Pada siklus I, dapat diketahui bahwa penerapan metode think fair share tentang kemampuan menulis teks pidato di kelas X-2 SMA Pasundan 2 Cianjur pada siklus I diperoleh nilai rata-rata siswa yaitu 70. Dari 23 siswa, sebanyak 6 siswa yang tidak tuntas karena nilai yang diperoleh belum mencapai KKM yang diharapkan. Nilai KKM yang ditentukan sekolah yaitu 80 sehingga presentase ketuntasan siswa yang diperoleh hanya sebesar 60,86\%, hal ini masih kurang dari kriteria yang diharapkan, karena belum mencapai KKM yang telah ditetapkan sekolah.

Pada siklus II, diperoleh hasil penilaian tes belajar sebagai berikut. Berdasarkan hasil rekapitulasi siklus II di atas, dapat disimpulkan bahwa pemahaman siswa terhadap materi menulis teks pidato mengalami peningkatan dibandingkan dengan siklus I, sehingga perbaikan dari siklus I bisa dikatakan berhasil. Jumlah nilai 1894 dan 
rata-rata nilai 82,34. Hal ini sudah sesuai dengan harapan penliti yaitu meningkatnya hasil belajar. Rata-rata nilai siswa sudah mampu melebihi KKM yang ditentukan yaitu 80. Jumlah siswa yang tuntas sebanyak 21 siswa sudah hampir semua tuntas, namun ada 2 siswa yang tidak tuntas karena tidak masuk sekolah. Tingkat keberhasilan siswa yang diperoleh pada siklus II sudah masuk pada kategori sangat baik yaitu 91,30\%.

Hal itu berarti bahwa taraf ketuntasan belajar siswa terhadap materi sudah mampu melebihi taraf yang ditentukan yaitu $80 \%$. Berdasarkan hasil tersebut, penerapan metode think fair share dapat meningkatkan kemampuan menulis teks pidato siswa kelas X-2 SMA Pasundan 2 Cianjur.

Berdasarkan analisis data terlihat peningkatan kemampuan menulis teks pidato. Setelah dirata-ratakan dari prasiklus, siklus I, dan siklus II. Peningkatan dari prasiklus ke siklus I sebesar 26,08\%. Dari siklus I ke siklus II pun terjadi peningkatan sebesar $30,44 \%$.

Pada tes prasiklus nilai rata-rata siswa sebesar 53,47 termasuk dalam kategori sangat kurang baik (rentang nilai 0-59). Pada siklus I nilai rata-rata siswa sebesar 70 dalam kategori cukup baik (rentang nilai 70-79) sedangkan pada siklus II nilai rata-rata hasil tes menjadi 82,34 dalam kategori baik (rentang nilai 8089). Peningkatan dari prasiklus ke siklus I sebesar 16,53. Pada siklus II mengalami peningkatan sebesar 12,34 dari hasil siklus I.

Hasil observasi aktivitas siswa pada siklus I. pada tabel 4 sebagai berikut. Berdasarkan perhitungan dapat diketahui bahwa aktivitas siswa siklus I tercatat 4 siswa atau sebesar $17,39 \%$ yang bermain handphone, 3 siswa atau sebesar $13,04 \%$ yang santai menunggu jawaban dari temannya, dan 2 siswa atau sebesar $8,69 \%$ yang menjaili temannya ketika mengerjakan. Hal ini, menunjukkan aktivitas siswa masih negatif.
Hasil observasi aktivitas siswa pada siklus II. pada tabel 5 sebagai berikut.

\section{Tabel : Hasil Rekapitulasi Aktivitas Siswa Siklus II.}

\begin{tabular}{|c|c|c|c|}
\hline No & Aspek yang diamati & $\mathbf{F}$ & $\%$ \\
\hline 1 & Bermain handphone. & 2 & $8,69 \%$ \\
\hline 2 & $\begin{array}{l}\text { Santai menunggu } \\
\text { jawaban dari temannya. }\end{array}$ & 0 & $0 \%$ \\
\hline 3 & $\begin{array}{l}\text { Menjaili temannya ketika } \\
\text { mengerjakan. }\end{array}$ & 0 & $0 \%$ \\
\hline
\end{tabular}

Berdasarkan tabel di atas pelaksanaan siklus II, aktivitas siswa yang bermain handphone 2 siswa atau sebesar 8,69\%, siswa yang santai menunggu jawaban dari temannya tidak ada, dan siswa yang menjaili temannya tidak ada.

Berdasarkan analisis data terlihat peningkatan aktivitas siswa dari hal negatif berubah menjadi positif.

\section{Pembahasan}

Kemampuan menulis teks pidato pada prasiklus, rata-rata mencapai 53,47 termasuk dalam kategori sangat kurang baik. Kemampuan siswa dalam menulis teks pidato masih rendah disebabkan oleh dua faktor yaitu faktor internal dan faktor eksternal. Faktor internal ini dapat dilihat pada kemampuan siswa dalam aspek bahasa yang masih kurang. Hal ini dapat dilihat pada hasil tes yang belum menunjukkan hasil yang memuaskan (belum mencapai kategori baik atau sangat baik). Adapun faktor eksternal berasal dari pola pembelajaran guru yang masih tradisional dan kurang bervariasi. Pola pembelajaran yang lebih mengutamakan teori, ceramah, monoton, dan terkesan hanya mengejar materi pelajaran tanpa pertimbangan pengalaman yang akan didapatkan siswa dalam pembelajaran.

Selanjutnya, hasil tes menulis teks pidato siklus I dengan rata-rata skor mencapai 70 dan termasuk kategori cukup. Hasil ini mengalami peningkatan sebesar 16,53 di mulai prasiklus. Meskipun hasil ini sudah 
mengalami peningkatan, tetapi nilai rata-rata ini belum mencapai target nilai yang telah ditetapkan.

Berikutnya, pada hasil tes menulis teks pidato siklus II, diperoleh nilai rata-rata 82,34 dan termasuk dalam kategori baik. Peningkatan skor rata-rata siklus I ke siklus II sebesar 12,34. Pencapaian skor ini menunjukkan bahwa pembelajaran menulis teks pidato pada siswa kelas X-2 SMA Pasundan 2 Cianjur dapat dikatakan berhasil karena sudah mencapai target yaitu berada pada kategori baik. Dengan demikian tindakan siklus III, tidak perlu dilakukan.

Hal tersebut menunjukkan adanya keselarasan penelitian tindakan kelas dengan teori yang dikemukakan oleh Arifin dan Tasai sebagai berikut.

"Menulis naskah pidato pada hakikatnya adalah menuangkan gagasan ke dalam bentuk bahasa tulis yang siap dilisankan. Pilihan kosakata, kalimat, dan paragraf dalam menulis sebuah pidato sesungguhnya tidak jauh berbeda dengan kegiatan menulis naskah yang lain. Situasi resmi atau kurang resmi akan menentukan kosakata dalam menulis." (Arifin dan Tasai, 2015: 209)

Menurut Arifin dan Tasai (2015: 208) berpendapat bahwa pidato yang baik ditandai oleh beberapa kriteria sebagai berikut. 1) isi pidato sesuai dengan kegiatan yang sedang berlangsung, 2) isinya menggugah dan bermanfaat bagi pendengar, 3) tidak menimbulkan pertentangan sara, 4) jelas, 5) benar dan objektif, 6) bahasa yang dipakai mudah dipahami, dan 7) disampaikan secara santun, rendah hati, dan bersahabat.

Selanjutnya, hasil observasi pada siklus I aktivitas siswa belum baik, masih ada beberapa siswa yang melakukan perilaku negatif walaupun jumlahnya lebih sedikit daripada siswa yang melakukan perilaku positif dalam mengikuti proses pembelajaran tersebut. Hal ini dibuktikan dengan data hasil observasi siswa yang tercatat 4 siswa atau sebesar 17,39\% yang bermain handphone, 3 siswa atau sebesar $13,04 \%$ yang santai menunggu jawaban dari temannya, dan 2 siswa atau sebesar $8,69 \%$ yang menjaili temannya ketika mengerjakan. Hal ini, menunjukkan aktivitas siswa masih negatif.

Pada siklus II sudah ada perubahan aktivitas siswa yaitu siswa sudah mengikuti pembelajaran menulis teks pidato dengan baik dan dapat menciptakan suasana belajar yang nyaman. Siswa tampak bersungguhsungguh dalam mengikuti penjelasan dan siswa sudah lebih aktif dalam mengikuti pelajaran dibandingkan pada siklus I. Perilaku negatif pada siklus I, pada siklus II banyak berkurang. Siswa yang melakukan perilaku negatif bermain handphone menjadi 2 siswa atau sebesar $8,69 \%$, siswa yang santai menunggu jawaban dari temannya tidak ada, dan siswa yang menjaili temannya tidak ada.

Berdasarkan hasil observasi aktivitas di atas perubahan aktivitas perilaku negatif yang terjadi pada siklus I menjadi aktivitas perilaku positif pada siklus II. Kondisi ini terjadi pada proses pembelajaran dengan memanfaatkan media pembelajaran sebagai alat bantu dalam penelitian. Hal ini terbukti dengan mengubah media pembelajaran hasilnya positif. Pada pelaksanaan penelitian siklus I menggunakan media cetak (contoh teks pidato) masih ada sejumlah siswa melakukan aktivitas perilaku negatif. Pada pelaksanaan siklus II dengan mengubah media pembelajaran menggunakan media audiovisual (video berpidato) perilaku negatif berkurang.

Arsyad (2007: 15) menyatakan bahwa "dalam suatu proses belajar mengajar, dua unsur yang amat penting adalah metode mengajar dan media pembelajaran". Bertolak dari sinilah media pembelajaran digunakan sebagai alat bantu penelitian tindakan kelas. Melalui bantuan media pembelajaran diharapkan dapat membangkitkan motivasi, rangsangan belajar, dan membawa pengaruh psikologi terhadap siswa sehingga siswa menjadi paham terhadap materi.

Selain itu, menurut Sadiman (2002: 6) memperjelas bahwa media merupakan segala sesuatu yang dapat digunakan untuk menyalurkan pesan dari pengirim ke penerima sehingga dapat merangsang pikiran, perasaan, perhatian, dan minat serta perhatian siswa sedemikian rupa sehingga proses belajar terjadi. 
Sedangkan menurut menurut Latuheru (1988:14) menyatakan bahwa media pembelajaran adalah bahan, alat, atau teknik yang digunakan dalam kegiatan belajar mengajar dengan maksud agar proses interaksi komunikasi dan edukasi antara guru dan siswa dapat berlangsung secara tepat guna dan berdaya guna.

Berdasarkan beberapa pendapat di atas, dapat disimpulkan bahwa media pembelajaran memiliki manfaat yang besar dalam memudahkan siswa mempelajari materi pelajaran.

Metode berasal dari kata methodos dalam bahasa Yunani yang berarti cara atau jalan. Salah satu cara yang digunakan oleh guru dalam proses pembelajaran yang hendak dicapai. Semakin tepat metode yang digunakan guru pembelajaran akan semakin baik.

Menurut Yamin (2013: 149) "metode pembelajaran merupakan cara guru melakukan atau menyajikan, menguraikan, memberi contoh, dan memberi latihan isi pelajaran kepada peserta didik untuk mencapai tujuan tertentu. Metode cara guru menjelaskan konsep, fakta, dan prinsip kepada peserta didik dengan cara pendekatan pembelajaran berpusat pada guru (teacher oriented) dan pembelajaran berpusat pada peserta didik (student oriented)".

Berdasarkan paparan di atas menunjukkan bahwa penelitian tindakan kelas yang dilakukan oleh peneliti tepat dalam memilih metode dan memilih media pembelajaran sebagai alat bantu penelitian.

\section{SIMPULAN}

Berdasarkan hasil pengumpulan data dan pengolahan data tentang kemampuan menulis teks pidato siswa kelas X-2 SMA Pasundan 2 Cianjur diperoleh simpulan sebagai berikut.
Kemampuan menulis teks pidato dengan menggunakan metode think fair share mengalami peningkatan. Pada tes prasiklus nilai rata-rata siswa sebesar 53,47 termasuk dalam kategori sangat kurang baik (rentang nilai 0-59). Pada siklus I nilai rata-rata siswa sebesar 70 atau dalam kategori cukup baik (rentang nilai 70-79) sedangkan pada siklus II nilai rata-rata hasil tes menjadi 82,34 dalam kategori baik (rentang nilai 80-89). Peningkatan dari prasiklus ke siklus I sebesar 16,53. Pada siklus II mengalami peningkatan sebesar 12,34 dari hasil siklus I. Hal ini menunjukkan bahwa setelah dilakukan perlakuan, kemampuan menulis teks pidato meningkat.

Peningkatan aktivitas siswa dalam mengikuti pembelajaran menulis teks pidato dengan menggunakan metode think fair share mengalami perubahan dari perilaku negatif berubah menjadi perilaku positif.

Data pada siklus I hasil observasi siswa yang tercatat ada 4 siswa atau sebesar $17,39 \%$ yang bermain handphone, 3 siswa atau sebesar $13,04 \%$ yang santai menunggu jawaban dari temannya, dan 2 siswa atau sebesar $8,69 \%$ yang menjaili temannya ketika mengerjakan. Hal ini, menunjukkan aktivitas siswa masih negatif.

Pada siklus II sudah ada perubahan aktivitas siswa tampak bersungguh-sungguh dalam mengikuti penjelasan dan siswa sudah lebih aktif dalam mengikuti pelajaran dibandingkan pada siklus I. Perilaku negatif pada siklus I, pada siklus II banyak berkurang. Siswa yang melakukan perilaku negatif bermain handphone menjadi 2 siswa atau sebesar $8,69 \%$, siswa yang santai menunggu jawaban dari temannya tidak ada, dan siswa yang menjaili temannya tidak ada.

Berdasarkan simpulan penelitian di atas, terdapat saran untuk peningkatan dan pengembangan kegiatan pembelajaran menulis teks pidato sebagai berikut.

Penerapan metode think fair share dapat dijadikan sebagai bahan acuan untuk 
mengadakan penelitian selanjutnya dari sudut permasalahan yang berbeda. Selain itu, dapat diimplementasikan sebagai bahan kajian metode pembelajaran bagi guru untuk diterapkan di SMA Pasundan 2 Cianjur sebagai alternatif metode pembelajaran menulis.

Perlu diperhatikan untuk peneliti selanjutnya dan guru bahwa proses belajar mengajar dengan metode think fair share merupakan jenis pembelajaran kooperatif yang dirancang untuk memengaruhi pola interaksi siswa. Hal ini dapat dilihat dalam langkah-langkah pembelajaran. Siswa melakukan diskusi dalam dua tahap yaitu tahap berpasangan (fair), diskusi dengan teman sebangku. Kemudian, tahap berbagi (share), diskusi dengan teman sekelasnya.

\section{DAFTAR PUSTAKA}

Arifin, E. Zaenal dan Tasai, S. Amran. 2015. Bahasa Indonesia sebagai Mata Kuliah Pengembangan Kepribadian. Tangerang: PT Pustaka Mandiri.

Dalman. 2014. Keterampilan Menulis. Jakarta: PT Raja Grafindo Persada.

Febrianto, Riko. 2015. Makalah Media Pembelajaran (Belajar dan Pembelajaran). [online]. Tersedia: http://syairiko.blogspot.co.id/2015/06/makalah-media-pembelajaran-belajardan.html. [18 April 2017].

Sanjaya, H. Wina. 2009. Penelitian Tindakan Kelas. Jakarta: Kencana Prenada Media Group.

Shoimin, Aris. 2016. 68 Model Pembelajaran Inovatif dalam Kurikulum 2013. Yogyakarta: Ar-ruzz Media.

Tarigan, Henry Guntur. 2008. Menulis sebagai suatu Keterampilan Berbahasa. Bandung: Angkasa. 